\title{
Phenotypic and Molecular-Phylogenetic Analysis Provide Novel Insights into the Diversity of Curtobacterium flaccumfaciens
}

\author{
Ebrahim Osdaghi,† S. Mohsen Taghavi, Silvia Calamai, Carola Biancalani, Matteo Cerboneschi, \\ Stefania Tegli, and Robert M. Harveson
}

First and second authors: Department of Plant Protection, College of Agriculture, Shiraz University, Shiraz 71441-65186, Iran; third, fourth, fifth, and sixth authors: Dipartimento di Scienze delle Produzioni Agroalimentari e dell'Ambiente, Laboratorio di Patologia Vegetale Molecolare, Università degli Studi di Firenze, Via della Lastruccia 10, 50019 Sesto Fiorentino, Firenze, Italy; and seventh author: University of Nebraska, Panhandle Research \& Extension Center, 4502 Ave. I., Scottsbluff 69361.

Accepted for publication 26 April 2018.

\begin{abstract}
A multiphasic approach was used to decipher the phenotypic features, genetic diversity, and phylogenetic position of 46 Curtobacterium spp. strains isolated from dry beans and other annual crops in Iran and Spain. Pathogenicity tests, resistance to arsenic compounds, plasmid profiling and BOX-PCR were performed on the strains. Multilocus sequence analysis (MLSA) was also performed on five housekeeping genes (i.e., atpD, gyrB, ppk, recA, and $r p o B$ ) of all the strains, as well as five pathotype strains of the species. Pathogenicity test showed that six out of 42 strains isolated in Iran were nonpathogenic on common bean. Despite no differences found between pathogenic and nonpathogenic strains in their plasmid profiling, the former were resistant to different concentrations of arsenic, while the latter were sensitive to the same

concentrations. Strains pathogenic on common bean were polyphyletic with at least two evolutionary lineages (i.e., yellow-pigmented strains versus red/orange-pigmented strains). Nonpathogenic strains isolated from solanaceous vegetables were clustered within either the strains of C. flaccumfaciens pv. flaccumfaciens or different pathovars of the species. The results of MLSA and BOX-PCR analysis were similar to each other and both methods were able to discriminate the yellowpigmented strains from the red/orange-pigmented strains. A comprehensive study of a worldwide collection representing all five pathovars as well as nonpathogenic strains of $C$. flaccumfaciens is warranted for a better understanding of the diversity within this phytopathogenic bacterium.
\end{abstract}

Curtobacterium flaccumfaciens inhabits multiple ecological niches, and includes environmental (Chase et al. 2016), humanpathogenic (Francis et al. 2011) plant-pathogenic (Osdaghi et al. 2015a), and plant beneficial (Raupach and Kloepper 2000) strains. The plant-pathogenic strains consist of five pathovars, namely C. flaccumfaciens pv. betae, $C$. flaccumfaciens pv. flaccumfaciens, C. flaccumfaciens pv. ilicis, C. flaccumfaciens pv. oortii, and $C$. flaccumfaciens pv. poinsettiae, the causal agents of silvering disease of red beet, bacterial wilt of dry beans (Fabaceae), bacterial blight of American holly, bacterial wilt and spot of tulip, and bacterial canker of poinsettia, respectively (Collins and Jones 1983; Dye and Kemp 1977). Among them, C. flaccumfaciens pv. flaccumfaciens is an economically important quarantine pathogen which causes bacterial wilt of dry beans in several States in North and South America, Asia and Oceania (EPPO 2011). C. flaccumfaciens is one of the most ambiguous and poorly understood plant pathogenic bacteria in terms of its biology, epidemiology and population genetics (Harveson et al. 2015). The bacterium also can colonize a number of plant species without inducing any disease symptoms (Gonçalves et al. 2017; Harveson et al. 2015; Osdaghi et al. 2018a). While orange, pink, purple and yellow colony variants of $C$. flaccumfaciens $\mathrm{pv}$. flaccumfaciens have been reported from the central high plains of

${ }^{\dagger}$ Corresponding author: E. Osdaghi; E-mail: eosdaghi@shirazu.ac.ir

Funding: Financial support for this study was co-provided by Shiraz University (Iran) and University of Florence (Italy).

*The $\boldsymbol{e}$-Xtra logo stands for "electronic extra" and indicates that four supplementary figures are published online.

(C) 2018 The American Phytopathological Society the United States (Agarkova et al. 2012), multicolored populations of the pathogen have been found in Canada (Huang et al. 2009) and Brazil (Soares et al. 2013). In addition to the yellow and orange-pigmented variants, a new red-pigmented variant of C. flaccumfaciens pv. flaccumfaciens has been recently isolated from common bean seeds in Iran (Osdaghi and Lak 2015b; Osdaghi et al. 2015a, 2016a). Differences in aggressiveness of C. flaccumfaciens pv. flaccumfaciens variants were observed when they were tested on various dry bean cultivars (Osdaghi et al. 2016a).

Nucleic acid sequence-based methods, such as multilocus sequence analysis (MLSA), have been developed to phylogenetically analyze the multiple core genes and to obtain clustering patterns of microorganisms. In particular, MLSA is a powerful and wellaccepted method to study the phylogeny of plant pathogenic bacteria (Jacques et al. 2012). While many MLSA studies have been conducted on several Gram-negative and Gram-positive plant pathogenic bacteria (Almeida et al. 2010; Jacques et al. 2012), no study has been conducted to determine the phylogenetic position of plant pathogenic C. flaccumfaciens strains. As a consequence, the relationships between the results of band-based fingerprinting (e.g., rep-PCR) and MLSA methods are yet to be determined for C. flaccumfaciens. In addition, unlike extensive molecular studies performed on several corynebacteria, (Gartemann et al. 2008), no information is available on mechanistic understanding of the virulence accessories and survival of $C$. flaccumfaciens on host plants, and other environmental habitats. This is a paradox based on the economic importance of this species, and the fact that high throughput techniques are available which could aid in making more accurate taxonomic classification.

The objectives of this study were to (i) determine the phenotypic characteristics (i.e., pathogenicity, arsenic resistance, and plasmid profile) of $C$. flaccumfaciens strains isolated from different annual 
crops in Iran, (ii) analyze the phylogenetic position of the C. flaccumfaciens strains isolated in Iran and Spain, in relation to all members of Curtobacterium spp., and (iii) compare the results with those of BOX-PCR fingerprinting and phenotypic characteristics of the strains.

\section{MATERIALS AND METHODS}

Bacterial strains. C. flaccumfaciens and Curtobacterium-like strains isolated in Iran during 2013 to 2016, from either symptomatic dry bean plants or asymptomatic solanaceous vegetables and squash (Cucurbita pepo), were used in this study (Table 1). The strains isolated from solanaceous vegetables were associated with either symptomatic or symptomless tomato and pepper plants in Iran (Osdaghi et al. 2016b, 2017a, 2018a). Additionally, pure DNA of four Curtobacterium spp. strains isolated from common bean seeds of germplasm bank in Spain (provided by Ana J. González; Horticultural and Forest Crops Area, SERIDA, Asturias, Spain) were included in molecular and phylogenetic analysis (González et al. 2005). In total, 51 strains, which include 46 strains from Iran and Spain, as well as the type strains of $C$. flaccumfaciens pv. flaccumfaciens (ICMP 2584), C. flaccumfaciens pv. betae (ICMP 2594), C. flaccumfaciens pv. ilicis (ICMP 2608), C. flaccumfaciens pv. oortii (ICMP 2632), and C. flaccumfaciens pv. poinsettiae

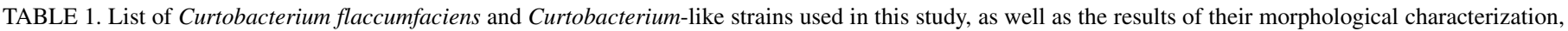
specific PCR, and pathogenicity tests ${ }^{\mathrm{a}}$

\begin{tabular}{|c|c|c|c|c|c|c|c|c|c|}
\hline \multirow[b]{2}{*}{ Strain } & \multirow[b]{2}{*}{ Morphology } & \multirow[b]{2}{*}{ Host of isolation } & \multirow{2}{*}{$\begin{array}{l}\text { Pathogenicity } \\
\text { on common } \\
\text { bean }\end{array}$} & \multirow{2}{*}{$\begin{array}{c}\text { CffFOR2/ } \\
\text { CffREV4 } \\
\text { PCR }\end{array}$} & \multicolumn{2}{|c|}{ Origin } & \multirow{2}{*}{$\begin{array}{l}\text { Date of } \\
\text { isolation }\end{array}$} & \multirow{2}{*}{$\begin{array}{l}\text { International } \\
\text { collection } \\
\text { number }\end{array}$} & \multirow[b]{2}{*}{ Reference } \\
\hline & & & & & Province & County & & & \\
\hline $10 \mathrm{eg}$ & Y-F & Eggplant & + & + & East Azerbaijan & Marand & 2014 & ICMP 22079 & Osdaghi et al. $2018 \mathrm{a}$ \\
\hline $50 \mathrm{R}$ & $\mathrm{R}-\mathrm{F}$ & Common bean & + & + & Markazi & Arak & 2014 & ICMP 22071 & Osdaghi et al. $2016 a$ \\
\hline 800 & $\mathrm{O}-\mathrm{F}$ & Common bean & + & + & Markazi & Arak & 2014 & ICMP 22069 & Osdaghi et al. $2016 \mathrm{a}$ \\
\hline $\mathrm{Cb} 222$ & Y-F & Common bean & + & + & East Azerbaijan & Marand & 2015 & ICMP 21399 & This study \\
\hline $\mathrm{Cb} 302$ & Y-F & Common bean & + & + & East Azerbaijan & Koshksaray & 2015 & - & This study \\
\hline Cb926 & Y-F & Common bean & + & + & Zanjan & Zanjan & 2015 & - & This study \\
\hline Cb935 & Y-F & Common bean & + & + & Zanjan & Zanjan & 2015 & - & This study \\
\hline Cff110 & Y-F & Common bean & + & + & Markazi & Khomein & 2014 & - & This study \\
\hline Cff113 & Y-F & Common bean & + & + & Markazi & Khomein & 2014 & - & This study \\
\hline Cff114 & Y-F & Common bean & + & + & East Azerbaijan & Marand & 2014 & - & This study \\
\hline Cff 120 & Y-F & Common bean & + & + & Markazi & Khomein & 2014 & - & This study \\
\hline Cff 130 & Y-F & Common bean & + & + & Markazi & Khomein & 2014 & - & This study \\
\hline Cff132 & $\mathrm{O}-\mathrm{F}$ & Common bean & + & + & Markazi & Arak & 2014 & - & This study \\
\hline Cff137 & $\mathrm{R}-\mathrm{F}$ & Common bean & + & + & Markazi & Arak & 2014 & ICMP 22066 & Osdaghi et al. $2016 \mathrm{a}$ \\
\hline Cff151 & $\mathrm{O}-\mathrm{F}$ & Common bean & + & + & Markazi & Arak & 2014 & - & This study \\
\hline Cff 153 & $\mathrm{O}-\mathrm{F}$ & Common bean & + & + & Markazi & Arak & 2014 & - & This study \\
\hline Cff155 & $\mathrm{O}-\mathrm{F}$ & Common bean & + & + & Markazi & Arak & 2014 & - & This study \\
\hline Cff156 & $\mathrm{O}-\mathrm{F}$ & Common bean & + & + & Markazi & Arak & 2014 & - & This study \\
\hline Cff204 & $\mathrm{O}-\mathrm{F}$ & Common bean & + & + & Fars & Kazerun & 2015 & ICMP 22068 & Osdaghi et al. $2016 a$ \\
\hline Cmmeg20 & $\mathrm{Y}-\mathrm{F}$ & Eggplant & - & - & Bushehr & Borazjan & 2014 & ICMP 22056 & Osdaghi et al. $2018 \mathrm{a}$ \\
\hline Cw101 & Y-F & Cowpea & + & + & Markazi & Delijan & 2015 & - & This study \\
\hline Cw104 & Y-F & Cowpea & + & + & East Azerbaijan & Koshksaray & 2015 & - & This study \\
\hline Cw110 & Y-F & Cowpea & + & + & East Azerbaijan & Marand & 2013 & - & This study \\
\hline Cw900 & Y-D & Cowpea & + & + & Khuzestan & Dezful & 2015 & - & This study \\
\hline Eg502 & Y-F & Eggplant & + & + & East Azerbaijan & Koshksaray & 2015 & ICMP 22055 & Osdaghi et al. $2018 \mathrm{a}$ \\
\hline Eg505 & Y-F & Eggplant & + & + & East Azerbaijan & Marand & 2015 & ICMP 22054 & Osdaghi et al. 2018a \\
\hline G105 & $\mathrm{R}-\mathrm{F}$ & Tomato & - & - & Bushehr & Borazjan & 2015 & ICMP 22064 & Osdaghi et al. $2018 \mathrm{a}$ \\
\hline G115 & $\mathrm{Y}-\mathrm{F}$ & Tomato & + & + & Fars & Khesht & 2015 & - & Osdaghi et al. $2018 \mathrm{a}$ \\
\hline K31 & Y-F & Tomato & + & + & Fars & Kazerun & 2015 & ICMP 22063 & Osdaghi et al. $2018 \mathrm{a}$ \\
\hline LPPA2199 & O-ND & Common bean & ND & - & Northern Spain & & 2006 & - & SERIDA* \\
\hline LPPA2315 & Y-ND & Common bean & ND & - & Northern Spain & & 2006 & - & SERIDA \\
\hline LPPA392 & Y-ND & Common bean & ND & - & Southern Spain & & 2005 & - & SERIDA \\
\hline LPPA987 & Y-ND & Common bean & ND & - & Northwestern Spa & & 2012 & - & SERIDA \\
\hline Mo01 & Y-F & Squash & - & - & Golestan & Gorgan & - & - & This study \\
\hline Mo04 & $\mathrm{O}-\mathrm{F}$ & Squash & - & - & Golestan & Gorgan & - & - & This study \\
\hline P701 & Y-F & Bell pepper & + & + & Zanjan & Zanjan & 2015 & ICMP 22078 & Osdaghi et al. $2018 \mathrm{a}$ \\
\hline P990 & Y-F & Bell pepper & + & + & Zanjan & Zanjan & 2015 & ICMP 22053 & Osdaghi et al. $2018 \mathrm{a}$ \\
\hline Tom50 & R-D & Tomato & + & + & Fars & Khesht & 2015 & ICMP 22062 & Osdaghi et al. $2018 \mathrm{a}$ \\
\hline Tom803 & Y-F & Tomato & + & + & East Azerbaijan & Marand & 2015 & ICMP 22083 & Osdaghi et al. $2018 \mathrm{a}$ \\
\hline Tom805 & Y-F & Tomato & + & + & West Azerbaijan & Urmia & 2015 & - & This study \\
\hline Tom806 & Y-F & Tomato & + & + & West Azerbaijan & Urmia & 2015 & ICMP 22059 & Osdaghi et al. $2018 \mathrm{a}$ \\
\hline Tom827 & Y-F & Tomato & - & - & East Azerbaijan & Marand & 2015 & ICMP 22084 & Osdaghi et al. $2018 \mathrm{a}$ \\
\hline Tom929 & Y-F & Tomato & + & + & Qazvin & Takestan & 2015 & - & This study \\
\hline Tom930 & Y-F & Tomato & + & + & Qazvin & Takestan & 2015 & ICMP 22057 & Osdaghi et al. $2018 \mathrm{a}$ \\
\hline Tom999 & Y-F & Tomato & + & + & Fars & Abadeh & 2015 & ICMP 22082 & Osdaghi et al. $2018 \mathrm{a}$ \\
\hline Xeu15 & Y-F & Chili pepper & - & - & East Azerbaijan & Marand & 2013 & ICMP 21400 & Osdaghi et al. $2018 \mathrm{a}$ \\
\hline ICMP 2594 & Y-D & Red beet & ND & - & United Kingdom & & 1955 & ICMP $2594^{\mathrm{T}}$ & ICMP \\
\hline ICMP 2584 & Y-F & Bean & ND & + & Hungary & & 1957 & ICMP $2584^{\mathrm{T}}$ & ICMP \\
\hline ICMP 2608 & Y-D & American holly & ND & - & USA & & 1960 & ICMP $2608^{\mathrm{T}}$ & ICMP \\
\hline ICMP 2632 & Y-D & Tulip & ND & - & Netherlands & & 1967 & ICMP $2632^{\mathrm{T}}$ & ICMP \\
\hline ICMP 2566 & $\mathrm{O}-\mathrm{D}$ & Poinsettia & ND & - & USA & & 1942 & ICMP $2566^{\mathrm{T}}$ & ICMP \\
\hline Tom835 & Y-M & Tomato & - & - & Iran & & 2015 & ICMP 22052 & Osdaghi et al. $2018 \mathrm{~b}$ \\
\hline ICMP 2550 & Y-M & Tomato & ND & - & Hungary & & 1957 & ICMP 2550 & ICMP \\
\hline Tom495 & Peach color-M & Tomato & ND & - & Iran & & 2015 & ICMP 22060 & Osdaghi et al. $2018 \mathrm{~b}$ \\
\hline
\end{tabular}

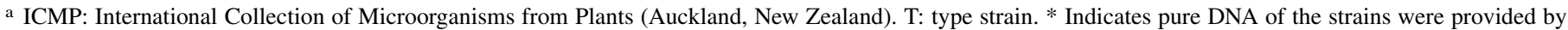
Ana J. González (Horticultural and Forest Crops Area, SERIDA, Apdo 13. 33300, Asturias, Spain). 
(ICMP 2566) were used in this study. Standard strains of Clavibacter michiganensis subsp. michiganensis (i.e., Tom835 = ICMP 22052, ICMP 2550, and NCPPB 382), as well as a nonpathogenic strain of Clavibacter spp. (Tom495 = ICMP 22060) were used as controls (Osdaghi et al. 2018b).

Morphological characteristics and pathogenicity tests of the strains. Morphological characteristics (e.g., colony color and fluidity) of the strains were determined on yeast extract-dextrosecalcium carbonate (YDC) agar medium, as well as nutrient agar (NA) medium supplemented with 5\% sucrose, after $72 \mathrm{~h}$ incubation as described by Smith et al. (2001). Briefly, colony morphology was subdivided into three categories: fluidal (colonies flowed when plates were inclined at $45^{\circ}$ ), mucoid (colonies had a glutinous consistency due to the production of polysaccharide), and dry (little or no polysaccharide was produced) (Smith et al. 2001).

Pathogenicity tests were conducted on common bean (Phaseolus vulgaris) plants (cultivar Dorsa) grown in glasshouse conditions using the bacterial strains reported in Table 1. Plant growth conditions and inoculum preparation were described previously (Osdaghi et al. 2015b). Plants were inoculated at the 10 to 12 days postemergence. For each strain, six common bean plants (three/ pot) were inoculated. Inoculation was made by inserting a sterile dissecting needle dipped into a fresh bacterial suspension $\left(1 \times 10^{8}\right.$ $\mathrm{CFU} / \mathrm{ml}$ ) throughout the internode between the first and the second node of each plant. All inoculated plants were maintained in the greenhouse at ambient temperature $\left(25\right.$ to $28^{\circ} \mathrm{C}$ and $14 \mathrm{~h}$ natural light). A reference strain of $C$. flaccumfaciens pv. flaccumfaciens (ICMP 22071) and sterile distilled water were used as positive and negative controls, respectively. Plants were periodically monitored for the appearance of disease symptoms and the final evaluation of disease symptoms was performed at 20 days postinoculation (dpi). Disease severity on each plant was rated based on the number of primary or trifoliate leaves showing wilting symptoms as described previously (Osdaghi et al. 2016a). Koch's postulates were accomplished by re-isolating the inoculated strains on yeast-extract peptone glucose agar (YPGA) medium from all inoculated plants. The identity of re-isolated bacterial strains was confirmed using the primer pair CffFOR2/CffREV4 (Tegli et al. 2002) (Table 2). Since six strains (i.e., Cmmeg20, G105, Mo01 Mo04, Tom827, and Xeu15) did not induce any symptoms on the inoculated common bean cultivar Dorsa plants, the same procedure as described above was conducted on common bean cultivars Derakhshan and Sadri and cowpea (Vigna unguiculata) cultivar Mashhad. All the pathogenicity tests were repeated twice.

Screening for arsenic resistance. We evaluated a set of 31 representative strains (Table 3) for their resistant response to different concentrations of two arsenic compounds (i.e., sodium arsenite $\left[\mathrm{NaAsO}_{2}\right]$ and sodium arsenate $\left.\left[\mathrm{Na}_{3} \mathrm{AsO}_{4}\right]\right)$. Type strain of C. flaccumfaciens pv. oortii (ICMP 2632) was used as positive control as recommended by Hendrick et al. (1984). We also included the standard strains of either pathogenic (i.e., ICMP 2550, NCPPB 382, and ICMP 22052), or nonpathogenic Clavibacter spp. (ICMP 22060) strains as negative controls (Osdaghi et al. 2018b).

The bacterial strains were screened using the agar plating method as described previously (Hendrick et al. 1984). Briefly, nutrient broth-yeast extract (NBY) agar plates supplemented with three different concentrations of either sodium arsenite $(2,5$, and $7 \mathrm{mM})$, or sodium arsenate $(80,100$, and $130 \mathrm{mM})$ were used for bacterial inoculation. For each strain, serial tenfold dilutions were prepared from a starter suspension $\left(\mathrm{OD}_{600}=2.5\right)$, obtained from a fresh culture grown at $27^{\circ} \mathrm{C}$ for $24 \mathrm{~h}$ on nutrient broth agar medium. For each dilution, 12 droplets (each droplet containing $5 \mu$ l of the suspension) were plated on each arsenic-containing plate. The plates were then incubated at $27^{\circ} \mathrm{C}$ for $48 \mathrm{~h}$, after which the number of single colony forming units (CFU) were counted. The data (average values \pm standard deviation [SD]) were subjected to one-way analysis of variance (ANOVA). Tukey's range test was also performed to identify statistically significant differences among the strains / salt concentrations, using PAST Version 3.17 (Hammer et al. 2001) (https://folk.uio.no/ohammer/past/).

Plasmid profiling. A set of 11 strains isolated in Iran was selected to carry out plasmid content analysis. This set was represented by candidate strains based on different isolation hosts and phenotypic features, including the type strain of $C$. flaccumfaciens pv. flaccumfaciens (ICMP 2584), pathogenic strains (50R, 80O, Cw110, P990, Tom50, and Tom930), as well as nonpathogenic strains (Cmmeg20, Mo04, Tom827, and Xeu15) of C.flaccumfaciens. The standard strains of Clavibacter michiganensis subsp. michiganensis (ICMP 2550 and NCPPB 382), harboring two plasmids (i.e., pCM1 and pCM2) (Meletzus et al. 1993) were also included in this study as positive controls.

Plasmids were isolated according to the procedure described by Klaenhammer (1984) with several modifications. The strains were grown overnight in $10 \mathrm{ml}$ of Luria-Bertani (LB) medium, on a $110 \mathrm{rpm}$ shaker at $27{ }^{\circ} \mathrm{C}$. Bacterial cells were pelleted by centrifugation $(6,000 \times g$ for $5 \mathrm{~min})$ and the pellets were resuspended in $1 \mathrm{ml}$ of Tris-EDTA (TE) buffer (pH 7.5), with $25 \%$ sucrose and $75 \mu \mathrm{l}$ of lysozyme ( $1 \mathrm{mg} \mathrm{ml}^{-1}$ in TE, $\left.\mathrm{pH} 7.5\right)$, and incubated at $37^{\circ} \mathrm{C}$ for $1 \mathrm{~h}$. Subsequently, $500 \mu \mathrm{l}$ of lysis solution was added to the bacterial pellet and the samples were heated at $62^{\circ} \mathrm{C}$ for $1 \mathrm{~h}$. Finally, plasmid DNA was neutralized by the addition of $50 \mu \mathrm{l}$ of $2 \mathrm{M}$ Tris (pH 7) and $70 \mu \mathrm{l}$ of $5 \mathrm{M} \mathrm{NaCl}$. The presence of plasmids was analyzed on $0.9 \%$ agarose gel at $60 \mathrm{~V}$ for 4 to $5 \mathrm{~h}$ in TAE buffer. Agarose gel was stained with ethidium bromide at $0.5 \mu \mathrm{g} / \mathrm{ml}$ and visualized with UV light using Gel Doc XR+ (BioRad). The experiments were repeated three times.

TABLE 2. Primer pairs used in this study

\begin{tabular}{|c|c|c|c|c|c|}
\hline Primer name & $5^{\prime}-3^{\prime}$ sequence & Target & $\begin{array}{c}\text { Size of } \\
\text { amplicon (bp) }\end{array}$ & $\begin{array}{c}\text { Annealing } \\
\text { temperature }\left({ }^{\circ} \mathrm{C}\right)\end{array}$ & Reference \\
\hline atpD2F & GACATCGAGTTCCCGCAC & atpD & 1,105 & 64 & Jacques et al. 2012 \\
\hline atpD2R & CGATGATCTCCTGGAGCTCCTTGT & & & & \\
\hline $2 \mathrm{~F}$ & ACCGTCGAGTTCGACTACGA & gyrB & 977 & 57 & Richert et al. 2005 \\
\hline $6 \mathrm{R}$ & AGSACGATCTTGTGGTA & & & & \\
\hline ppkCfF & GAGAACCTCATCCAGGCCCT & $p p k$ & 604 & 63 & This study \\
\hline ppkCfR & CGAGCTTCGAGTGCGTCTTCAG & & & & \\
\hline recACfF & GACCGCACTCGCCCAGATCGACCG & recA & 723 & 66 & This study \\
\hline recACfR & GCCATCTTGTTCTTCACGACCTTG & & & & \\
\hline $3 \mathrm{Fs}$ & GACAACTTCTACTTCAAC & rрoB & 447 & 55 & Richert et al. 2007 \\
\hline 4Rs & GTTGTTCTGGTCCATGAAC & & & & \\
\hline CffFOR2 & GTTATGACTGAACTTCACTCC & C. flaccumfaciens pv. flaccumfaciens & 306 & 62 & Tegli et al. 2002 \\
\hline CffREV4 & GATGTTCCCGGTGTTCGA & & & & \\
\hline ERIC1R & ATGTAAGCTCCTGGGGATTCAC3 & ERIC & - & 42 & Versalovic et al. 1994 \\
\hline ERIC2 & AAGTAAGTGACTGGGGTGAGCG & & & & \\
\hline BOXA1R & CTACGCCAAGGCGACGCCTGACG & BOX & - & 52 & Versalovic et al. 1994 \\
\hline REPIR-I & IIICGICGICATCIGGC & REP & - & 42 & Versalovic et al. 1994 \\
\hline REP2I & ICGICTTATGIGGCCTAC & & & & \\
\hline
\end{tabular}


DNA extraction, PCRs, and sequencing. DNA extraction was performed using Expin Combo-GP DNA extraction kit (GeneAll, Tic Tech Centre, Singapore) based on the manufacturer's recommendations. The quality and quantity of the DNAs were spectrophotometrically evaluated and adjusted to $50 \mathrm{ng} \mu \mathrm{l}^{-1}$ using Nanodrop ND-100 (Nanodrop Technologies, Waltham, MA). The DNA was kept at $-20^{\circ} \mathrm{C}$ for further uses. Five housekeeping genes including atpD, gyrB, $p p k$, recA, and $r p o B$ were employed for the sequencing and phylogenetic analyses on all the strains described in Table 1. Primer pairs were used for partial sequencing of atpD, gyrB, and $r p o B$ as described previously (Table 2) (Jacques et al. 2012; Richert et al. 2005, 2007). While the primer pairs ppkCfF/ ppkCfR and recACfF/recACfR were redesigned for $p p k$ and $r e c A$ genes, respectively, based on the sequence of Curtobacterium sp. (strain MR_MD2014, GenBank: CP009755.1) (Mariita et al. 2015) according to Jacques et al. (2012) (Table 2). For PCR reactions, Universal PCR Kit, Ampliqon Taq DNA Polymerase Master Mix Red (Ampliqon A/S, Odense, Denmark), was used according to the manufacturer's recommendations. For each strain, a $25 \mu \mathrm{l}$ of PCR including $50 \mathrm{ng}$ of total DNA and $1 \mu \mathrm{l}$ of each primer $\left(10 \mathrm{pmol} \mu \mathrm{l}^{-1}\right)$ were used. Purity and yield of PCR products were checked by running a $5-\mu l$ reaction mixture in $1.2 \%$ agarose gel stained with ethidium bromide. The PCR products were sent to Bioneer Corporation (www.Bioneer.com) (Daejeon, South Korea) to be sequenced using Sanger sequencing technology.

Resulting sequences were analyzed using the BLAST program (https://blast.ncbi.nlm.nih.gov/) and aligned with Clustal W program (Larkin et al. 2007) implemented in MEGA 6.06 software (Tamura et al. 2013). Partial sequences were deposited in the NCBI GenBank and assigned accession numbers as follows: atpD: KX591664 to KX591707 and MG737698 to MG737699; gyrB: KX591708 to KX591751, and MG737700 to MG737701; ppk: KX591752 to KX591795, and MG737702 to MG737703; recA: KX591796 to KX591839, and MG737704 to MG737705; and rpoB: KX591840 to KX591883, and MG737706 to MG737707. For phylogenetic comparisons, the respective sequences of the five housekeeping genes were retrieved from 30 publicly available complete genome sequences of Curtobacterium spp. strains in the GenBank database.

Phylogenetic analysis. Sequences were concatenated following the alphabetic order of the genes, ending in a sequence of 2,977 bp: nucleotides 1 to 761 for atpD, 762 to 1507 for $g y r B$ (746 bp), 1508 to 2021 for ppk (514 bp), 2022 to 2612 for recA (591 bp), and 2613 to 2977 for $r p o B$ (365 bp). Phylogenetic analyses were performed on individual gene sequences as well as the data set of concatenated sequences. Phylogenetic trees were constructed using maximum likelihood method with MEGA 6.06 software (Tamura et al. 2013). The general time-reversible (GTR) model of evolution was selected for Maximum Likelihood analysis using the Modeltest tab in MEGA 6.06 (Hall, 2011). Clavibacter michiganensis subsp. michiganensis strain NCPPB 382 was used to root the trees. MEGA 6.06 was used to obtain the phylogenetic trees and bootstrap values (1000 replicates) for the nucleotide sequences of each individual gene and of concatenated sequences. Additionally,

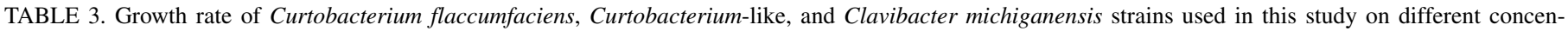
trations of sodium arsenite $\left(\mathrm{NaAsO}_{2}\right)$ and sodium arsenate $\left(\mathrm{Na}_{3} \mathrm{AsO}_{4}\right)^{\mathrm{a}}$

\begin{tabular}{|c|c|c|c|c|c|c|c|c|}
\hline \multirow[b]{3}{*}{ Strain } & & \multicolumn{6}{|c|}{ Resistance to } & \multirow{3}{*}{$\begin{array}{c}\text { Pathogenicity } \\
\text { on common } \\
\text { bean }\end{array}$} \\
\hline & & \multicolumn{3}{|c|}{ Sodium arsenite } & \multicolumn{3}{|c|}{ Sodium arsenate } & \\
\hline & & $2 \mathrm{mM}^{\mathrm{s}}$ & $5 \mathrm{mM}^{\mathrm{s}}$ & $7 \mathrm{mM}^{\mathrm{s}}$ & $80 \mathrm{mM}^{\mathrm{s}}$ & $100 \mathrm{mM}^{\mathrm{s}}$ & $130 \mathrm{mM}^{\mathrm{s}}$ & \\
\hline C. flaccumfaciens pv. flaccumfaciens & $10 \mathrm{eg}$ & $10^{2}-10^{4}$ & $\leq 10^{2}$ & $\leq 10^{2}$ & $10^{4}-10^{6}$ & $10^{4}-10^{6}$ & $10^{2}-10^{4}$ & + \\
\hline C. flaccumfaciens pv. flaccumfaciens & $50 \mathrm{R}$ & $10^{4}-10^{6}$ & $\leq 10^{2}$ & $\leq 10^{2}$ & $10^{4}-10^{6}$ & $10^{4}-10^{6}$ & $10^{2}-10^{4}$ & + \\
\hline C. flaccumfaciens pv. flaccumfaciens & 800 & $10^{2}-10^{4}$ & $\leq 10^{2}$ & $\leq 10^{2}$ & $10^{4}-10^{6}$ & $10^{4}-10^{6}$ & $10^{2}-10^{4}$ & + \\
\hline C. flaccumfaciens pv. flaccumfaciens & $\mathrm{Cb} 222$ & $10^{2}-10^{4}$ & $\leq 10^{2}$ & $\leq 10^{2}$ & $10^{4}-10^{6}$ & $10^{4}-10^{6}$ & $10^{2}-10^{4}$ & + \\
\hline C. flaccumfaciens pv. flaccumfaciens & $\mathrm{Cb} 302$ & $10^{2}-10^{4}$ & $\leq 10^{2}$ & $\leq 10^{2}$ & $10^{4}-10^{6}$ & $10^{4}-10^{6}$ & $10^{2}-10^{4}$ & + \\
\hline C. flaccumfaciens pv. flaccumfaciens & $\mathrm{Cb} 926$ & $10^{2}-10^{4}$ & $\leq 10^{2}$ & $\leq 10^{2}$ & $10^{4}-10^{6}$ & $10^{4}-10^{6}$ & $10^{2}-10^{4}$ & + \\
\hline C. flaccumfaciens pv. flaccumfaciens & Cff110 & $10^{2}-10^{4}$ & $\leq 10^{2}$ & $\leq 10^{2}$ & $10^{4}-10^{6}$ & $10^{4}-10^{6}$ & $10^{2}-10^{4}$ & + \\
\hline C. flaccumfaciens pv. flaccumfaciens & Cff137 & $10^{2}-10^{4}$ & $\leq 10^{2}$ & $\leq 10^{2}$ & $10^{4}-10^{6}$ & $10^{4}-10^{6}$ & $10^{2}-10^{4}$ & + \\
\hline C. flaccumfaciens pv. flaccumfaciens & Cff151 & $10^{2}-10^{4}$ & $\leq 10^{2}$ & $\leq 10^{2}$ & $10^{4}-10^{6}$ & $10^{4}-10^{6}$ & $10^{2}-10^{4}$ & + \\
\hline C. flaccumfaciens pv. flaccumfaciens & Cff153 & $10^{2}-10^{4}$ & $\leq 10^{2}$ & $\leq 10^{2}$ & $10^{4}-10^{6}$ & $10^{4}-10^{6}$ & $10^{2}-10^{4}$ & + \\
\hline C. flaccumfaciens pv. flaccumfaciens & Cff 155 & $10^{2}-10^{4}$ & $\leq 10^{2}$ & $\leq 10^{2}$ & $10^{4}-10^{6}$ & $10^{4}-10^{6}$ & $10^{2}-10^{4}$ & + \\
\hline C. flaccumfaciens pv. flaccumfaciens & Cff156 & $10^{2}-10^{4}$ & $\leq 10^{2}$ & $\leq 10^{2}$ & $10^{4}-10^{6}$ & $10^{4}-10^{6}$ & $10^{2}-10^{4}$ & + \\
\hline C. flaccumfaciens pv. flaccumfaciens & ICMP $2584^{\mathrm{T}}$ & $\leq 10^{2}$ & - & - & $\leq 10^{2}$ & $\leq 10^{2}$ & $\leq 10^{2}$ & + \\
\hline C. flaccumfaciens pv. flaccumfaciens & Cw101 & $10^{2}-10^{4}$ & $\leq 10^{2}$ & $\leq 10^{2}$ & $10^{4}-10^{6}$ & $10^{4}-10^{6}$ & $10^{2}-10^{4}$ & + \\
\hline C. flaccumfaciens pv. flaccumfaciens & Cw110 & $10^{4}-10^{6}$ & $\leq 10^{2}$ & $\leq 10^{2}$ & $10^{4}-10^{6}$ & $10^{4}-10^{6}$ & $10^{2}-10^{4}$ & + \\
\hline C. flaccumfaciens pv. flaccumfaciens & Eg502 & $10^{2}-10^{4}$ & $\leq 10^{2}$ & $\leq 10^{2}$ & $10^{4}-10^{6}$ & $10^{4}-10^{6}$ & $10^{2}-10^{4}$ & + \\
\hline C. flaccumfaciens pv. flaccumfaciens & Eg505 & $10^{2}-10^{4}$ & $\leq 10^{2}$ & $\leq 10^{2}$ & $10^{4}-10^{6}$ & $10^{4}-10^{6}$ & $10^{2}-10^{4}$ & + \\
\hline C. flaccumfaciens pv. flaccumfaciens & Mo11 & $10^{2}-10^{4}$ & $\leq 10^{2}$ & $\leq 10^{2}$ & $10^{4}-10^{6}$ & $10^{4}-10^{6}$ & $10^{2}-10^{4}$ & + \\
\hline C. flaccumfaciens pv. flaccumfaciens & P701 & $10^{2}-10^{4}$ & $\leq 10^{2}$ & $\leq 10^{2}$ & $10^{4}-10^{6}$ & $10^{4}-10^{6}$ & $10^{2}-10^{4}$ & + \\
\hline C. flaccumfaciens pv. flaccumfaciens & P990 & $10^{2}-10^{4}$ & $\leq 10^{2}$ & $\leq 10^{2}$ & $10^{4}-10^{6}$ & $10^{4}-10^{6}$ & $10^{2}-10^{4}$ & + \\
\hline C. flaccumfaciens pv. flaccumfaciens & Tom50 & $10^{2}-10^{4}$ & $\leq 10^{2}$ & $\leq 10^{2}$ & $10^{4}-10^{6}$ & $10^{4}-10^{6}$ & $10^{2}-10^{4}$ & + \\
\hline C. flaccumfaciens pv. flaccumfaciens & Tom803 & $10^{2}-10^{4}$ & $\leq 10^{2}$ & $\leq 10^{2}$ & $10^{4}-10^{6}$ & $10^{4}-10^{6}$ & $10^{2}-10^{4}$ & + \\
\hline C. flaccumfaciens pv. flaccumfaciens & Tom806 & $10^{2}-10^{4}$ & $\leq 10^{2}$ & $\leq 10^{2}$ & $10^{4}-10^{6}$ & $10^{4}-10^{6}$ & $10^{2}-10^{4}$ & + \\
\hline C. flaccumfaciens pv. flaccumfaciens & Tom930 & $10^{2}-10^{4}$ & $\leq 10^{2}$ & $\leq 10^{2}$ & $10^{4}-10^{6}$ & $10^{4}-10^{6}$ & $\leq 10^{2}$ & + \\
\hline C. flaccumfaciens pv. flaccumfaciens & Tom999 & $10^{2}-10^{4}$ & $\leq 10^{2}$ & $\leq 10^{2}$ & $10^{4}-10^{6}$ & $10^{4}-10^{6}$ & $10^{2}-10^{4}$ & + \\
\hline C. flaccumfaciens pv. oortii & ICMP $2632^{\mathrm{T}}$ & $10^{2}-10^{4}$ & $\leq 10^{2}$ & $\leq 10^{2}$ & $10^{4}-10^{6}$ & $10^{4}-10^{6}$ & $10^{4}-10^{6}$ & - \\
\hline C. flaccumfaciens & Cmmeg20 & - & - & - & - & - & - & - \\
\hline C. flaccumfaciens & G105 & - & - & - & - & - & - & - \\
\hline C. flaccumfaciens & Tom827 & - & - & - & - & - & - & - \\
\hline C. flaccumfaciens & Xeu15 & - & - & - & - & - & - & - \\
\hline Curtobacterium spp. & $\mathrm{Mo04}$ & - & - & - & - & - & - & - \\
\hline Clavibacter michiganensis subsp. michiganensis & ICMP $2550^{\mathrm{T}}$ & - & - & - & - & - & - & - \\
\hline Clavibacter michiganensis subsp. michiganensis & NCPPB 382 & - & - & - & - & - & - & - \\
\hline Clavibacter michiganensis subsp. michiganensis & Tom835 & - & - & - & - & - & - & - \\
\hline Clavibacter spp. & Tom495 & - & - & - & - & - & - & - \\
\hline
\end{tabular}

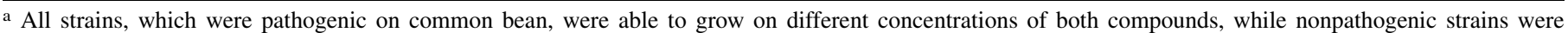
sensitive. Clavibacter michiganensis strains were sensitive to both the compounds regardless of their pathogenicity on tomato. S = data statistically significant (ANOVA and Tukey's test, $P<0.05$ ). 
the similarity matrix of the concatenated sequences of five housekeeping genes, in the type strains of five pathovars of C. flaccumfaciens, was prepared using the online service "Sequence Identity And Similarity" (SIAS) (http://imed.med.ucm.es/Tools/sias.html) with default settings.

Recombination analysis. Nucleotide diversity, the number of haplotypes, and haplotype diversity were determined using DnaSP 5.10 software (Librado and Rozas 2009). The class I neutrality tests (Tajima's D and Fu, and Li's D* and $\mathrm{F}^{*}$ ) were also calculated for detecting potential departure from the mutation/drift equilibrium (Librado and Rozas 2009). Detection of potential recombinant sequences and identification of likely parental sequences within $C$. flaccumfaciens strains were conducted using a set of seven nonparametric detection methods (i.e., RDP, Geneconv, MaxChi, Chimaera, BootScan, SiScan, and 3Seq) implemented in Recombination Detection Program (RDP) version 4.80 (Martin et al. 2015). The analysis was performed with default settings for the different detection methods, and the Bonferroni-corrected $\mathrm{P}$ value cutoff was set at 0.05 . Two independent experiments, one including all the Curtobacterium sp. strains and the other including only $C$. flaccumfaciens strains, were performed in this analysis. Recombination events were accepted when they were identified by at least four out of seven detection methods (Martin et al. 2015). Splits-decomposition network was constructed and the pairwise homoplasy index (PHI) was calculated using SplitsTree version 4.14.4 (Huson and Bryant 2006). These calculations used the individual genes, as well as the entire data set of concatenated sequences (Huson and Bryant 2006).

Rep-PCR. Since the MLSA-based phylogeny was unable to differentiate pathogenic and nonpathogenic strains, BOX, enterobacterial repetitive intergenic consensus (ERIC), and repetitive element palindromic (REP) primers (Table 2) (Versalovic et al. 1994) were used to discriminate the putative diversity among C. flaccumfaciens strains from our collection. Fifty-one C. flaccumfaciens and one Clavibacter michiganensis (as out-group) strains were evaluated with rep-PCR analysis (Table 1). PCR reactions were similar to those described above, while the annealing temperatures are described in Table 2. Ten microliters of PCR products was run on $1.2 \%$ agarose gel, stained with ethidium bromide, and the digitized image was converted into a TIFF file for a subsequent analysis of the fingerprint patterns. Unweighted pair groups with arithmetic averages were calculated using NTSYS-pc software version 2.02e (Rohlf 2008). The procedure was repeated independently to test the reproducibility of the fingerprints.

\section{RESULTS}

Morphology and pathogenicity of the strains. Morphological characteristics of the strains are presented in Table 1. Among the bacterial strains isolated in Iran, all but two (i.e., Cw900 and Tom50) were shown to have fluidal colony on YDC medium. The strains Cw900 and Tom50 have had dried colonies on the same medium (Table 1). As for colony color, 30 strains had

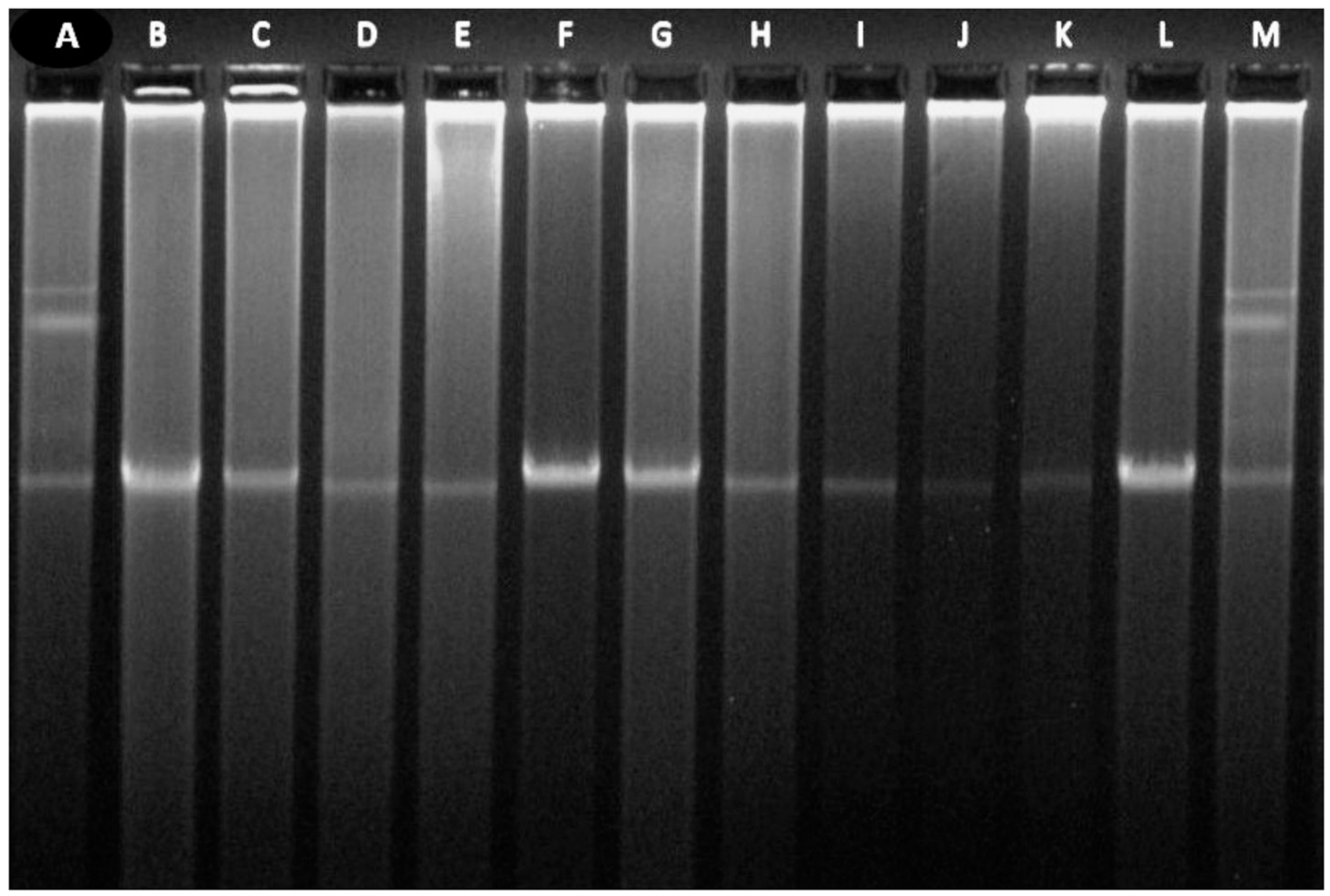

Fig. 1. Plasmid profile of Curtobacterium flaccumfaciens and Curtobacterium-like strains used in this study. Indigenous plasmids from Clavibacter michiganensis subsp. michiganensis (pCM1 and pCM2), whose sizes were 27.5 and $72 \mathrm{~kb}$, respectively, were used as positive control. Chromosomal DNAs are seen as a common band in all strains. Lanes A and M, Clavibacter michiganensis subsp. michiganensis ICMP 2550 and NCPB 382, respectively; lane B, ICMP 2584; lane C, P990; lane D, Tom50; lane E, 50R; lane F, 80O; lane G, Tom827; lane H, Tom930; lane I, Xeu15; lane J, Cmmeg20; lane K, Cw110; and lane L, Mo04. No indigenous plasmids were found in C. flaccumfaciens and Curtobacterium-like strains used in this study. 
yellow colonies, while eight were orange and four were redpigmented (Table 1; Supplementary Fig. S1).

All the C. flaccumfaciens strains isolated from dry beans in Iran were pathogenic on common bean in greenhouse conditions (Table 1). Interveinal chlorosis, leading to necrotic areas on the leaves, and systemic wilting were observed at 8 to 14 days postinoculation (Supplementary Fig. S2). Among the strains isolated from solanaceous vegetables, all but four (i.e., Cmmeg20, G105, Tom827, and Xeu15) were pathogenic on common bean (Table 1). None of the strains isolated from squash (i.e., Mo01 and Mo04) were pathogenic on common bean. After inoculation, bacterial strains were re-isolated from the symptomatic plants, and

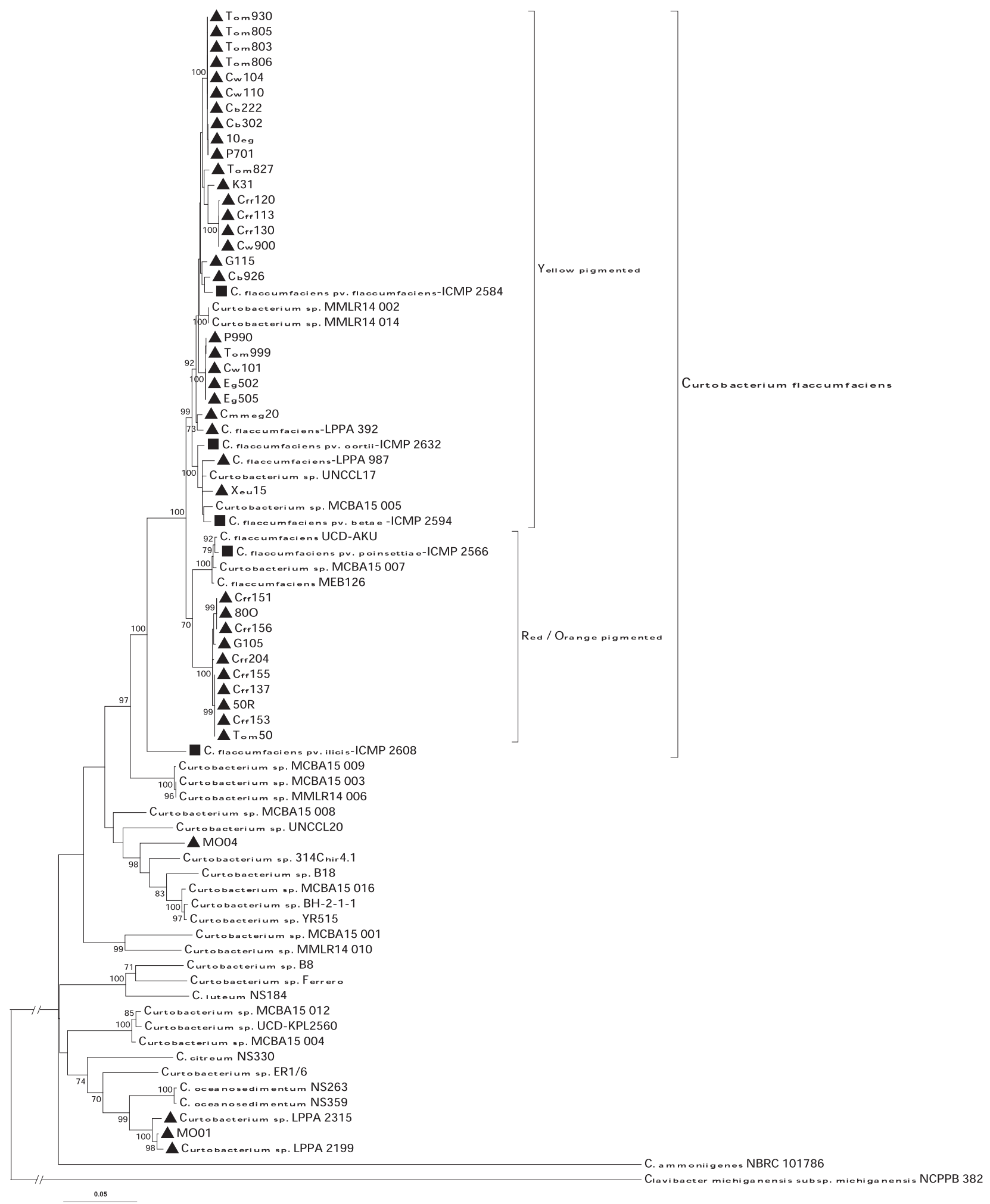

Fig. 2. Maximum likelihood tree based on the concatenated partial sequences of atpD, gyrB, ppk, recA, and rpoB genes in Curtobacterium flaccumfaciens and Curtobacterium-like strains used in this study. Bootstrap scores (1,000 replicates) are displayed at each node. Clavibacter michiganensis was used for rooting the tree. Yellow-pigmented strains of $C$. flaccumfaciens were phylogenetically different from those of red/orange-pigmented strains. Nonpathogenic strains of C. flaccumfaciens were scattered among the pathogenic strains. The strains isolated in Iran and Spain were labeled using black triangles, while the type strains of five pathovars of $C$. flaccumfaciens were labeled using black squares. 
identified using specific PCR primers CffFOR2/CffREV4 (data not shown). Repetitive pathogenicity tests on common bean cultivars Derakhshan and Sadri, as well as on cowpea cultivar Mashhad with Cmmeg20, G105, Tom827, Xeu15, Mo01, and Mo04 strains produced similar results to those observed in the first set of pathogenicity tests. Control plants remained healthy.

Resistance to arsenic. All but five of the evaluated strains were resistant against arsenic compounds. The strains Cmmeg20, G105, Tom827, Xeu15, and Mo04 were unable to grow on any concentration of either sodium arsenite and sodium arsenate (Table 3). The level of resistance to arsenic compounds in the type strain of C. flaccumfaciens pv. flaccumfaciens (ICMP 2584) was statistically different from those of other strains. It was able to grow on sodium arsenite up to $2 \mathrm{mM}$ (Table 3), with faint growth on all concentrations of sodium arsenate. None of the Clavibacter spp. strains evaluated was able to grow on arsenic compounds regardless of their pathogenicity status on tomato.

Plasmid profiling. As expected, Clavibacter michiganensis subsp. michiganensis strains ICMP 2550 and NCPPB 382 harbored two plasmids (pCM1 and pCM2); whose sizes were 27.5 and $72 \mathrm{~kb}$, respectively (Fig. 1, lanes A and M). No plasmids were found in any of the C. flaccumfaciens strains tested here, regardless of their isolation host or pathogenicity on common bean (Fig. 1, lanes B to L).

Phylogenetic analysis. Phylogenetic analysis showed a clustering pattern based on colony color of $C$. flaccumfaciens strains used in this study (Fig. 2). Considering the data set of concatenated sequences of five housekeeping genes, the phylogenetic tree was strongly supported by a $100 \%$ bootstrap value, clear differentiation of yellow-pigmented C. flaccumfaciens strains from red/orangepigmented strains (Fig. 2).

All the yellow-pigmented strains of $C$. flaccumfaciens clustered as a monophyletic group containing the nonpathogenic strains (i.e., Tom827, Cmmeg20, and Xeu15) isolated from solanaceous vegetables in Iran, as well as a number of cosmopolitan strains isolated from different environmental habitats (Fig. 2). The yellowpigmented strains 10eg, Cb222, Cb302, Cw104, Cw110, P701, Tom803, Tom805, Tom806, and Tom930-all of which were isolated in northwestern Iran in 2015-were clustered as one haplotype (Table 1). This observation is consistent with the epidemic emergence of the bacterial wilt disease from all the northwestern provinces of the country in 2015. Nonpathogenic red-pigmented strain G105 was clustered among the other red/orange-pigmented pathogenic strains irrespective of their host of isolation. Furthermore, the strains LPPA2315, LPPA2199, and Mo01 were clustered as a monophyletic group apart from the core population of C. flaccumfaciens. Based on the results of MLSA data, none of the strains Mo01, Mo04, LPPA2315, and LPPA2199 are true members of $C$. flaccumfaciens. In all the five phylogenetic trees constructed using the individual housekeeping gene sequences, yellowpigmented $C$. flaccumfaciens strains were separated from the red/ orange-pigmented strains. Interestingly, there were no differences

TABLE 4. Sequence statistics of the five housekeeping genes (i.e., atpD, gyrB, $p p k$, recA, and rpoB) of Curtobacterium flaccumfaciens strains used in this study

\begin{tabular}{lcccccc}
\hline & \multicolumn{6}{c}{ Diversity parameters $^{\mathrm{a}}$} \\
\cline { 2 - 7 } Sequence & $\mathrm{N}$ & $\mathrm{H}$ & \multicolumn{1}{c}{$\mathrm{S}$} & $\mathrm{Pi}$ & $\mathrm{NM}$ & $\mathrm{HD}$ \\
\hline atpD & 761 & 47 & 108 & 0.02091 & 124 & 0.964 \\
gyrB & 746 & 53 & 203 & 0.05783 & 267 & 0.983 \\
ppk & 514 & 46 & 130 & 0.06187 & 173 & 0.963 \\
recA & 591 & 48 & 138 & 0.05561 & 184 & 0.970 \\
rpoB & 365 & 33 & 66 & 0.04405 & 71 & 0.863 \\
Concatenated & 2,977 & 54 & 645 & 0.04696 & 819 & 0.983 \\
\hline
\end{tabular}

a $\mathrm{N}$ : number of nucleotides; $\mathrm{H}$ : number of haplotypes; $\mathrm{S}$ : total number of segregating sites; Pi: nucleotide diversity; $(\pi)$; NM: number of mutations $(\eta)$; and HD: haplotype (gene) diversity. among all the yellow-pigmented $C$. flaccumfaciens strains in the $r p o B$ gene sequence (data not shown).

Sequence statistics of the five housekeeping genes used for the phylogenetic analysis are summarized in Table 4. Among the 75 C. flaccumfaciens and Curtobacterium spp. strains used in this study, the highest number of haplotypes (53 haplotypes) were observed in $g y r B$ gene sequences. Conversely, only 33 haplotypes were observed in $r p o B$ gene sequences using the same number of strains (Table 4). Altogether, gyrB and $r e c A$ genes were the most discriminative, and $r p o B$ was the least discriminative gene for C. flaccumfaciens phylogeny evaluations (Table 4).

Sequence similarity matrix experiments using five housekeeping gene sequences showed that four pathotypes of $C$. flaccumfaciens (i.e., C. flaccumfaciens pv. betae, C. flaccumfaciens pv. flaccumfaciens, $C$. flaccumfaciens pv. oortii, and C. flaccumfaciens pv. poinsettiae) are closely related to each other with sequence similarity ranging between 97.31 to $99.09 \%$ (Table 5). However, C. flaccumfaciens pv. ilicis (previously known as Arthrobacter ilicis) (Young et al. 2004), which recently been included in C. flaccumfaciens species, is distinct from the core population of other C. flaccumfaciens isolates (Fig. 2). Indeed, the sequence similarity between C. flaccumfaciens pv. ilicis and the other four pathovars of the species is only 95.53 to $95.93 \%$ (Table 5).

Tajima's D, and Fu and Li's D* and F* statistics showed that there was no significant departure from the mutation drift equilibrium within $C$. flaccumfaciens strains used in this study (data not shown). Because the maximum likelihood phylogenies showed incompatible topologies (Fig. 2; Supplementary Fig. S3), phylogenetic networks were generated using the splits-decomposition method for the concatenated data set (Fig. 3), as well as all the individual gene sequences (data not shown). Considering the C. flaccumfaciens strains, pairwise homoplasy index (PHI) test did find statistically significant evidence suggesting the occurrence of recombination among the $g y r B$ (PhiTest $=0.27568 ; P<0.02386$ ) and recA (PhiTest $=0.22906 ; P<0.3122)$ genes but not in the atpD, ppk, and $r p o B$ genes. Recombination Detection Program (RDP) discovered recombination in both the data set of Curtobacterium spp. strains, and $C$. flaccumfaciens strains (Table 6). Indeed, recombination was detected in the $C$. flaccumfaciens strains from all the seven tested methods. Additionally, when the individual gene sequences were considered using RDP, recombination was identified in $g y r B$ (in six out of seven methods), recA (in four out of seven methods), and $r p o B$ (in four out of seven methods) genes sequences.

Genetic diversity of the strains. ERIC-PCR produced 0 to 4 fragments in sizes ranging from 0.2 to $2 \mathrm{~kb}$, while REP-PCR produced 0 to 3 fragments in sizes ranging from 0.1 to $3 \mathrm{~kb}$ (data not shown). Primer BOX A1R produced 4 to 12 fragments in sizes ranging from 0.2 to $2.6 \mathrm{~kb}$ (Supplementary Fig. S4). Hence, BOX A1R primer was selected to evaluate the genetic diversity of our collection of 51 C. flaccumfaciens strains. The dendrogram based on UPGMA cluster analysis showed all $C$. flaccumfaciens strains forming a group with similarity coefficient ranged from 31 to $93 \%$

TABLE 5. Similarity matrix of the concatenated sequences of five housekeeping genes (i.e., atpD, gyrB, ppk, recA, and $r p o B$ ) in five pathotype strains of Curtobacterium flaccumfaciens

\begin{tabular}{lrrrrr}
\hline & ICMP & ICMP & ICMP & ICMP & ICMP \\
Strain $^{\mathrm{a}}$ & 2584 & 2594 & 2566 & 2632 & 2608 \\
\hline ICMP 2584 & 100.00 & & & & \\
ICMP 2594 & 98.25 & 100.00 & & & \\
ICMP 2566 & 97.71 & 97.31 & 100.00 & & \\
ICMP 2632 & 98.52 & 99.09 & 97.61 & 100.00 & \\
ICMP 2608 & 95.83 & 95.73 & 95.53 & 95.93 & 100.00 \\
\hline
\end{tabular}

a ICMP 2584: C. flaccumfaciens pv. flaccumfaciens; ICMP 2594: C. flaccumfaciens pv. betae; ICMP 2566: C. flaccumfaciens pv. poinsettiae; ICMP 2632: C. flaccumfaciens pv. oortii; and ICMP 2608: C. flaccumfaciens pv. ilicis. 
(Fig. 4). Cluster analysis using a cutoff level at $44 \%$ similarity produced six clusters (named G1 to G6) - two of them were major clusters (G1 $=25$ and $\mathrm{G} 2=16$ strains) and four minor clusters (one to four strains). Cluster G1 included both yellow-pigmented and red/orange-pigmented strains, while clusters G2-G6 incorporated only yellow-pigmented strains. The strains in G1 were subclustered into three subgroups namely G1-1 to G1-3, with similarity values between 56 to $93 \%$. All but one strain (Cff155) in G1-1 were yellowpigmented, while the strains in G1-2 were red/orange-pigmented, except the strain LPPA392. The cluster G1-3 contained three strains, all of them isolated from tomato, and two of them (G105 and Tom827) were nonpathogenic on bean plants (Fig. 4; Table 1). Cluster G2 had similarity coefficients ranging from 55 to $91 \%$ and contained 15 yellow-pigmented strains in G2-1 and strain 10eg in G2-2 subclusters (Fig. 4). Cluster G3, contained four strains, which further divided into two subclusters in $49 \%$ cutoff value similarity. Cluster G4 contained four strains, three of which were isolated from in Spain (LPPA2199, LPPA2315, and LPPA987), and the type strain of C. flaccumfaciens pv. poinsettiae. Finally, cluster G5 contained only one strain (P701) as did cluster G6 (the type strain of C. flaccumfaciens pv. oortii) (Fig. 4).

The most prominent feature in the BOX-PCR fingerprint of C. flaccumfaciens is a band of approximately $500 \mathrm{bp}$, which is present in all the strains except for LPPA2199, LPPA2315, and the type strain of C. flaccumfaciens pv. poinsettiae. This is an interesting result because the strains LPPA2199 and LPPA2315 (G4-1) were isolated in Spain and were clustered apart from the core population of C. flaccumfaciens in MLSA-based phylogenetic trees (Fig. 2). A fragment of approximately 430 to $460 \mathrm{bp}$ was produced in Clavibacter michiganensis but not in the C. flaccumfaciens strains. No discernible differences were found between C. flaccumfaciens strains isolated from dry beans and those isolated from asymptomatic solanaceous vegetables.

\section{DISCUSSION}

In this study, a multiphasic approach was used to decipher the phenotypic features, genetic diversity and phylogeny of C. flaccumfaciens strains isolated in Iran and Spain. Although no differences were found between the pathogenic and nonpathogenic strains in their plasmid profile, the former were resistant against all evaluated concentrations of arsenic compounds, while the latter were sensitive to the same concentrations. MLSA results revealed that the bacterial strains causing wilt disease on dry beans were distributed into two phylogenetic lineages (yellow-pigmented strains and red/ orange-pigmented strains).

Most of the plant-pathogenic bacteria are reported to have nonpathogenic lineages (Jacques et al. 2012). For instance,

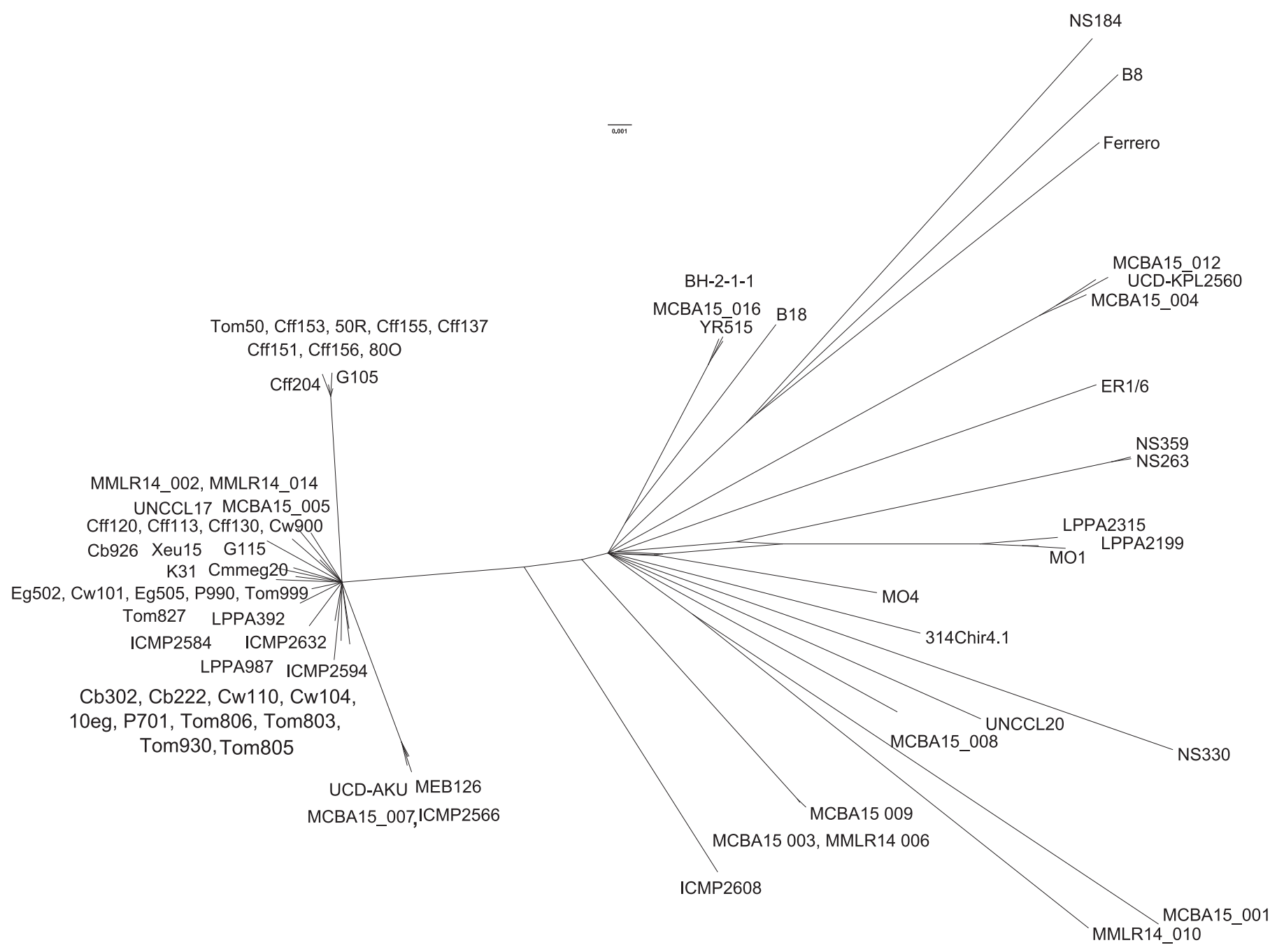

Fig. 3. Splits decomposition network generated from the concatenated sequences of atpD, gyrB, ppk, recA, and rpoB genes of Curtobacterium flaccumfaciens and Curtobacterium-like strains used in this study. All the red/orange-pigmented strains of $C$. flaccumfaciens pv. flaccumfaciens were clustered separately from the yellow-pigmented strains, while the type strain of $C$. flaccumfaciens pv. poinsettiae (ICMP 2566) was clustered within the cosmopolitan strains. Interestingly, the type strain of $C$. flaccumfaciens pv. ilicis (ICMP 2608) was clustered far from the core population of $C$. flaccumfaciens similar to that observed in multilocus sequence analysis scheme (Fig. 2). 
nonpathogenic strains of Clavibacter michiganensis were reported to be isolated frequently from tomato seeds (Yasuhara-Bell and Alvarez 2015). Multiphasic studies, including pathogenicity tests, MLSA, and plasmid profiling, revealed that these strains form a separate phylogenetic group and thus could be considered as new subspecies namely Clavibacter michiganensis subsp. californiensis and Clavibacter michiganensis subsp. chilensis (Thapa et al. 2017; Yasuhara-Bell and Alvarez 2015). However, nonpathogenic strains of $C$. flaccumfaciens did not form a separate phylogenetic

TABLE 6. Test of recombination among Curtobacterium flaccumfaciens and Curtobacterium-like strains using RDP4 with a Bonferroni test at a probability of 0.05

\begin{tabular}{lccccc}
\hline & \multicolumn{2}{c}{ Curtobacterium sp. } & & \multicolumn{2}{c}{ C. flaccumfaciens } \\
\cline { 2 - 3 } \cline { 5 - 6 } Test & $\begin{array}{c}\text { Unique } \\
\text { events }\end{array}$ & $\begin{array}{c}\text { Recombination } \\
\text { signals }\end{array}$ & & $\begin{array}{c}\text { Unique } \\
\text { events }\end{array}$ & $\begin{array}{c}\text { Recombination } \\
\text { signals }\end{array}$ \\
\hline RDP & 4 & 4 & & 1 & 1 \\
GENECONV & 4 & 4 & & 1 & 1 \\
BootScan & 6 & 6 & & 2 & 2 \\
MaxChi & 8 & 8 & & 1 & 1 \\
Chimaera & 6 & 8 & & 1 & 1 \\
SiScan & 9 & 11 & & 2 & 3 \\
3Seq & 4 & 4 & & 3 & 11 \\
Total & 14 & 44 & & 4 & \\
\hline
\end{tabular}

group and were scattered either within the core population of C. flaccumfaciens pv.flaccumfaciens or within the other pathovars of the species.

We have demonstrated that unlike the nonpathogenic strains (i.e., Cmmeg20, G105, Tom827, Xeu15, and Mo04), the C. flaccumfaciens pv. flaccumfaciens strains which were pathogenic on common bean were resistant to arsenic compounds. The association between arsenic resistance and pathogenicity on common bean remains to be elucidated, although this could be due to the adaptation of $C$. flaccumfaciens pv. flaccumfaciens on bean plants. Indeed, common bean is an arsenic-accumulating plant (CarbonellBarrachina et al. 1997; Stoeva et al. 2005). More specifically, C. flaccumfaciens pv. flaccumfaciens strains from Iran showed a higher resistance to arsenic compared to the type strain, which was originally isolated in Hungary. A high arsenic content was observed in surface and ground waters in several Iranian provinces, which might have favored the adaptation of the pathogen to this compound (Keshavarzi et al. 2011). However, no correlation was found between arsenic resistance and the MLSA data. Further analysis is needed to determine the effect of arsenic on the relationships of C. flaccumfaciens pv. flaccumfaciens and its hosts, as recently studied for the legume-rhizobia interaction (Lafuente et al. 2015).

In the original description of $C$. flaccumfaciens pathovars, it has been noticed that $C$. flaccumfaciens pv. betae, $C$. flaccumfaciens pv. flaccumfaciens, C. flaccumfaciens pv. oortii, and C. flaccumfaciens

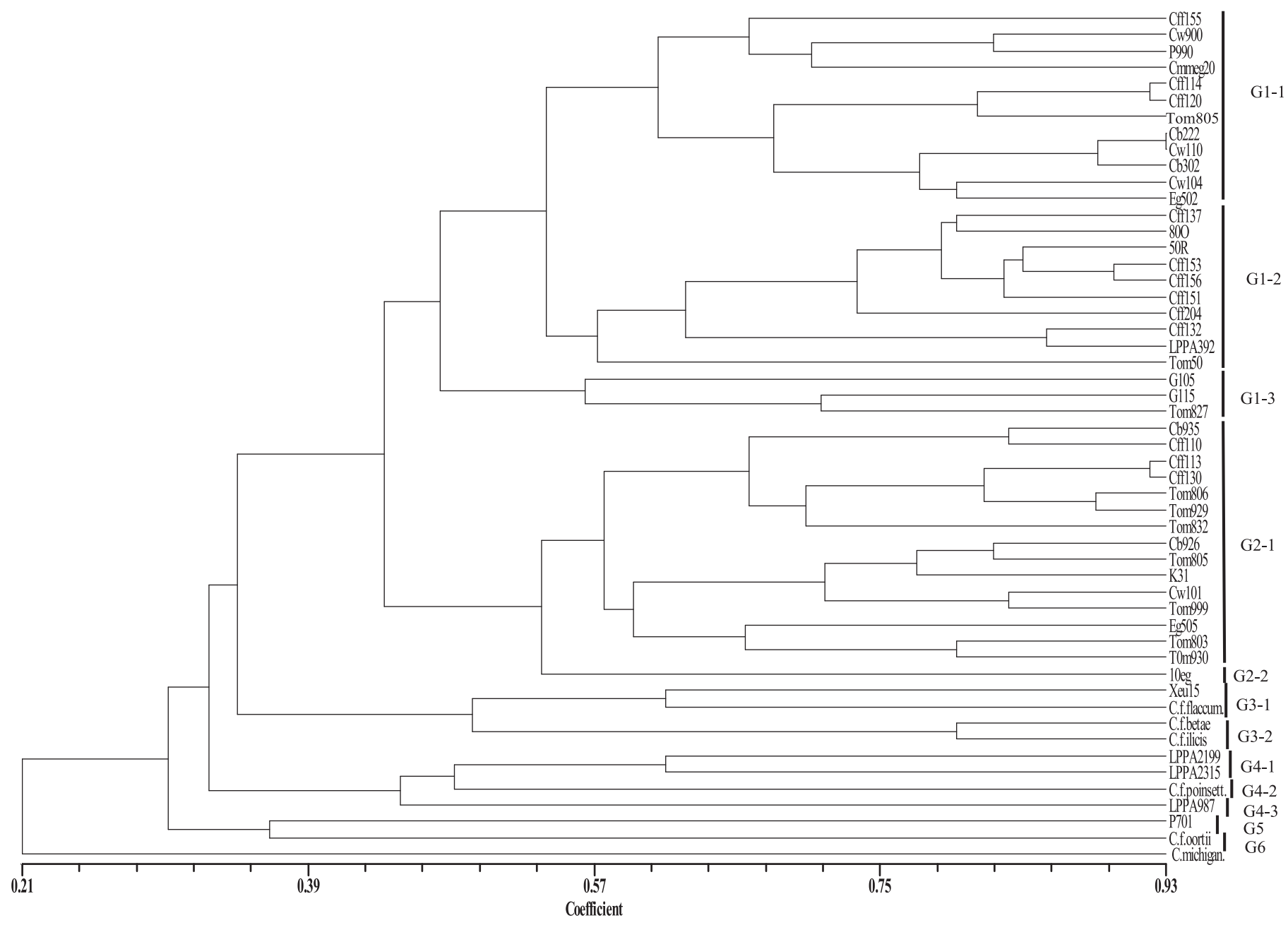

Fig. 4. Dendrogram generated from BOX-PCR fingerprints of Curtobacterium flaccumfaciens strains used in this study. Cluster analysis was performed using the simple matching similarity coefficient and unweighted pair group with arithmetic averages using NTSYS-pc software version 2.02e. The scale bar indicates levels of linkage between patterns. Cluster analysis using a cutoff level at $44 \%$ similarity produced six clusters (named G1 to G6) - two of them major (G1 = 25 and G2 = 16 strains) and four were minor (one to four strains) clusters. Red/orange-pigmented strains of $C$. flaccumfaciens were distinguished from the yellow-pigmented strains. 
pv. poinsettiae are closely related to each other in terms of biochemical and physiological characteristics, and differences in host specificity and bacteriocin production are insufficient to justify differentiation at the subspecies level (Collins and Jones 1983; Dye and Kemp 1977). MLSA results from this study revealed that these four pathovars belong to the same species with 97.31 to $99.09 \%$ similarity in five housekeeping genes sequences (Table 5). However, $C$. flaccumfaciens pv. ilicis is distinct from the core population of $C$. flaccumfaciens pv. flaccumfaciens (Fig. 2). By contrast, it has been shown that phylogenetic distance between the yellowpigmented strains of $C$. flaccumfaciens $\mathrm{pv}$. flaccumfaciens and the red/orange-pigmented strains is higher than that of the distances among the type strains of $C$. flaccumfaciens pv. betae, C. flaccumfaciens pv. flaccumfaciens, and C. flaccumfaciens pv. oortii (Fig. 2; Table 5), all included in the cluster of yellow-pigmented C. flaccumfaciens pv. flaccumfaciens strains (Fig. 2; Table 5). Altogether, these results suggest that the taxonomy of $C$. flaccumfaciens should be reexamined using a large collection of strains from all the five pathovars of the species. Unlike to the other plant pathogenic corynebacteria, no molecular high throughput method to date has been used to confirm the classical taxonomy of C. flaccumfaciens proposed in late 1970s (Collins and Jones 1983; Dye and Kemp 1977). Recently, whole genome sequence analysis based on average nucleotide identity (ANI), digital DNA-DNA hybridization, and MLSA of seven housekeeping genes supported the concept of raising many Clavibacter michiganensis subspecies to five new species/combination level ( $\mathrm{Li}$ et al. 2017). A similar approach has been started for the members of C. flaccumfaciens using the complete genome sequencing of type /pathotype strains of the species (Osdaghi et al. 2017b, 2018a).

In conclusion, the results obtained in this study provide several new findings, including the phylogenetic relationships between the two different lineages (i.e., yellow-pigmented strains versus red/ orange-pigmented strains) of the bean pathogen $C$. flaccumfaciens pv. flaccumfaciens, as well as the remaining four pathovars of C. flaccumfaciens. Results of MLSA and phenotypic features (i.e., colony color) are in congruence among C. flaccumfaciens strains, although further detailed and multiphasic evaluations are needed to determine if the different colony variants of $C$. flaccumfaciens pv.flaccumfaciens could be reclassified as different subspecies/ pathovars of the species. We also found a distinctive phenotypic feature (arsenic resistance) which is capable to discriminating pathogenic strains of $C$. flaccumfaciens from nonpathogenic strains. However, a comprehensive multiphased study using a collection of worldwide isolates should illustrate the phylogenetic history and intraspecies relationships of $C$. flaccumfaciens strains.

\section{ACKNOWLEDGMENTS}

Pure DNA of the strains isolated in Spain were provided by A. J. González (Cultivos Hortofrutícolas y Forestales, SERIDA, Villaviciosa, Asturias, Spain). We thank J. Ram Lamichhane (UMR AGIR, INRA, Castanet-Tolosan, France) for critical reading of the first draft of the manuscript. E. Osdaghi thanks DISPAA, University of Florence, for financial support during his sabbatical stay in Italy.

\section{LITERATURE CITED}

Agarkova, I. V., Lambrecht, P. A., Vidaver, A. K., and Harveson, R. M. 2012. Genetic diversity among Curtobacterium flaccumfaciens pv. flaccumfaciens populations in the American High Plains. Can. J. Microbiol. 58:788-801.

Almeida, N. F., Yan, S., Cai, R., Clarke, C. R., Morris, C. E., Schaad, N. W., Schuenzel, E. L., Lacy, G. H., Sun, X., and Jones, J. B. 2010. PAMDB, a multilocus sequence typing and analysis database and website for plantassociated microbes. Phytopathology 100:208-215.

Carbonell-Barrachina, A. A., Burlò, J. F., Mataix, J., Burgos-Hernkdez, A., Lopez, E., and Mataix, J. 1997. The influence of arsenite concentration on arsenic accumulation in tomato and bean plants. Sci. Hortic. (Amsterdam) 71:167-176.

Chase, A. B., Arevalo, P., Polz, M. F., Berlemont, R., and Martiny, J. B. H. 2016. Evidence for ecological flexibility in the cosmopolitan genus Curtobacterium. Front. Microbiol. 7:1874.
Collins, M. D., and Jones, D. 1983. Reclassification of Corynebacterium flaccumfaciens, Corynebacterium betae, Corynebacterium oortii and Corynebacterium poinsettiae in the genus Curtobacterium, as Curtobacterium flaccumfaciens comb. nov. J. Gen. Microbiol. 129:3545-3548.

Dye, D. W., and Kemp, W. J. 1977. A taxonomic study of plant pathogenic Corynebacterium species. N.Z. J. Agric. Res. 20:563-582.

EPPO. 2011. Curtobacterium flaccumfaciens pv. flaccumfaciens. Bull. OEPP/ EPPO Bull. 41:320-328.

Francis, M. J., Doherty, R. R., Patel, M., Hamblin, J. F., Ojaimi, S., and Korman, T. M. 2011. Curtobacterium flaccumfaciens septic arthritis following puncture with a Coxspur Hawthorn thorn. J. Clin. Microbiol. 49:2759-2760.

Gartemann, K. H., Abt, B., Beke, T., Burger, A., Engemann, J., Flugel, M., Gaigalat, L., Goesmann, A., Grafen, I., Kalinowski, J., Kaup, O., Kirchner, O., Krause, L., Linke, B., McHardy, A., Meyer, F., Pohle, S., Ruckert, C., Schneiker, S., Zellermann, E., Puhler, A., Eichenlaub, R., Kaiser, O., and Bartels, D. 2008. The genome sequence of the tomatopathogenic actinomycete Clavibacter michiganensis subsp. michiganensis NCPPB382 reveals a large island involved in pathogenicity. J. Bacteriol. 190:2138-2149.

Gonçalves, R. M., Schipanski, C. A., Koguishi, L., Soman, J. M., Sakate, R. K., Silva Júnior, T. A. F., and Maringoni, A. C. 2017. Alternative hosts of Curtobacterium flaccumfaciens pv. flaccumfaciens, causal agent of bean bacterial wilt. Eur. J. Plant Pathol. 148:357-365.

González, A. J., Tello J. C., Rodicio, M. R., 2005. Bacterial wilt of beans (Phaseolus vulgaris) caused by Curtobacterium flaccumfaciens in Southeastern Spain. Plant Dis. 89:1361.

Hall, B. G. 2011. Phylogenetic Trees Made Easy, a How To Manual. 4th ed., Sinauer Associate Inc., Sunderland, MA.

Hammer, Ø., Harper, D. A. T., and Ryan, P. D. 2001. PAST: Paleontological statistics software package for education and data analysis. Palaeontol. Electronica 4:1-9.

Harveson, R. M., Schwartz, H. F., Urrea, C. A., and Yonts, C. D. 2015. Bacterial wilt of dry-edible beans in the Central High Plains of the U.S.: Past, present, and future. Plant Dis. 99:1665-1677.

Hendrick, C. A., Haskins, W. P., and Vidaver, A. K. 1984. Conjugative plasmid in Corynebacterium flaccumfaciens subsp. oortii that confers resistance to arsenite, arsenate, and antimony(III). Appl. Environ. Microbiol. 48:56-60.

Huang, H. C., Erickson, R. S., Balasubramanian, P. M., Hsieh, T. F., and Conner, R. L. 2009. Resurgence of bacterial wilt of common bean in North America. Can. J. Plant Pathol. 31:290-300.

Huson, D. H., and Bryant, D. 2006. Application of phylogenetic networks in evolutionary studies. Mol. Biol. Evol. 23:254-267.

Jacques, M. A., Durand, K., Orgeur, G., Balidas, S., Fricot, C., Bonneau, S., Quillévéré, A., Audusseau, C., Olivier, V., Grimault, V., and Mathis, R. 2012. Phylogenetic analysis and polyphasic characterization of Clavibacter michiganensis strains isolated from tomato seeds reveal that non-pathogenic strains are distinct from C. michiganensis subsp. michiganensis. Appl. Environ. Microbiol. 78:8388-8402.

Keshavarzi, B., Moore, F., Mosaferi, M., and Rahmani, F. 2011. The source of natural arsenic contamination in groundwater, west of Iran. Water Qual. Expo. Health 3:135-147.

Klaenhammer, T. R. 1984. A general method for plasmid isolation in lactobacilli. Curr. Microbiol. 10:23-28.

Lafuente, A., Pérez-Palacios, P., Doukkali, B., Molina-Sánchez, M. D., Jiménez-Zurdo, J. I., Caviedes, M. A., Rodríguez-Llorente, I. D., and Pajuelo, E. 2015. Unraveling the effect of arsenic on the model Medicago-Ensifer interaction: A transcriptomic meta-analysis. New Phytol. 205:255-272.

Larkin, M. A., Blackshields, G., Brown, N. P., Chenna, R., McGettigan, P. A., McWilliam, H., Valentin, F., Wallace, I. M., Wilm, A., Lopez, R., Thompson, J. D., Gibson, T. J., and Higgins, D. G. 2007. ClustalW and ClustalX version 2. Bioinformatics 23:2947-2948.

Li, X., Tambong, J., Yuan, K., Chen, W., Xu, H., Lévesque, C. A., and De Boer, S. H. 2017. Re-classification of Clavibacter michiganensis subspecies on the basis of whole-genome and multi-locus sequence analyses. Int. J. Syst. Evol. Microbiol. 68:234-240.

Librado, P., and Rozas, J. 2009. DnaSP v5: a software for comprehensive analysis of DNA polymorphism data. Bioinformatics 25:1451-1452.

Mariita, R. M., Bhatnagar, S., Hanselmann, K., Hossain, M. J., Korlach, J., Boitano, M., Roberts, R. J., Liles, M. R., Moss, A. G., Leadbetter, J. R., Newman, D. K., and Dawson, S. C. 2015. Complete genome sequence of Curtobacterium sp. strain MR_MD2014, isolated from topsoil in Woods Hole, Massachusetts. Genome Announc. 3:e01504-e01515.

Martin, D. P., Murrell, B., Golden, M., Khoosal, A., and Muhire, B. 2015. RDP4: Detection and analysis of recombination patterns in virus genomes. Virus Evol. 1:vev003.

Meletzus, D., Bermphol, A., Dreier, J., and Eichenlaub, R. 1993. Evidence for plasmid-encoded virulence factors in the phytopathogenic bacterium Clavibacter michiganensis subsp. michiganensis NCPPB382. J. Bacteriol. 175:2131-2136. 
Osdaghi, E., Ansari, M., Taghavi, S. M., Zarei, S., Koebnik, R., and Lamichhane, J. R. 2018b. Pathogenicity and phylogenetic analysis of Clavibacter michiganensis strains associated with tomato plants in Iran. Plant Pathol. 67:957-970.

Osdaghi, E., Forero Serna, N., Bolot, S., Fischer-Le Saux, M., Jacques, M.-A., Portier, P., Carrère, S., and Koebnik, R. 2017b. High-quality draft genome sequence of Curtobacterium sp. strain Ferrero. Genome Announc. 5: e01378-e17.

Osdaghi, E., and Lak, M. R. 2015. Occurrence of a new orange variant of Curtobacterium flaccumfaciens pv. flaccumfaciens, causing common bean wilt in Iran. J. Phytopathol. 163:867-871.

Osdaghi, E., Pakdaman Sardrood, B., Bavi, M., Akbari Oghaz, N., Kimiaei, S., and Hadian, S. 2015a. First report of Curtobacterium flaccumfaciens pv. flaccumfaciens causing cowpea bacterial wilt in Iran. J. Phytopathol. 163: 653-656.

Osdaghi, E., Taghavi, S. M., Fazliarab, A., Elahifard, E., and Lamichhane, J. R. 2015b. Characterization, geographic distribution and host range of Curtobacterium flaccumfaciens: An emerging bacterial pathogen in Iran. Crop Prot. 78:185-192.

Osdaghi, E., Taghavi, S. M., Hamzehzarghani, H., Fazliarab, A., Harveson, R. M., and Lamichhane, J. R. 2016a. Occurrence and characterization of a new red-pigmented variant of Curtobacterium flaccumfaciens, the causal agent of bacterial wilt of edible dry beans in Iran. Eur. J. Plant Pathol. 146: 129-145.

Osdaghi, E., Taghavi, S. M., Hamzehzarghani, H., Fazliarab, A., Harveson, R. M., Tegli, S., and Lamichhane, J. R. 2018a. Epiphytic Curtobacterium flaccumfaciens strains isolated from symptomless solanaceous vegetables are pathogenic on leguminous but not on solanaceous plants. Plant Pathol. 67: $388-398$

Osdaghi, E., Taghavi, S. M., Hamzehzarghani, H., Fazliarab, A., and Lamichhane, J. R. 2017a. Monitoring the occurrence of tomato bacterial spot and range of the causal agent Xanthomonas perforans in Iran. Plant Pathol. 66:990-1002.

Osdaghi, E., Taghavi, S. M., Hamzehzarghani, H., and Lamichhane, J. R. 2016b. Occurrence and characterization of the bacterial spot pathogen Xanthomonas euvesicatoria on pepper in Iran. J. Phytopathol. 164:722-734.

Raupach, G. S., and Kloepper, J. W. 2000. Biocontrol of cucumber diseases in the field by plant-growth promoting rhizobacteria with and without methyl bromide fumigation. Plant Dis. 84:1073-1075.

Richert, K., Brambilla, E., and Stackebrandt, E. 2005. Development of PCR primers specific for the amplification and direct sequencing of gyrB genes from microbacteria, order Actinomycetales. J. Microbiol. Methods 60: $115-123$

Richert, K., Brambilla, E., and Stackebrandt, E. 2007. The phylogenetic significance of peptidoglycan types: Molecular analysis of the genera Microbacterium and Aureobacterium based upon sequence comparison of gyrB, rpoB, recA and ppk and 16SrRNA genes. Syst. Appl. Microbiol. 30: 102-108.

Rohlf, F. J. 2008. NTSYSpc: Numerical Taxonomy System, ver. 2.20. Exeter Publishing, Ltd., Setauket, NY.

Smith, N. C., Hennessy, J., and Stead, D. E. 2001. Repetitive sequence-derived PCR profiling using the BOX-A1R primer for rapid identification of the plant pathogen Clavibacter michiganensis subspecies sepedonicus. Eur. J. Plant Pathol. 107:739-748.

Soares, R. M., Fantinato, G. G. P., Darben, L. M., Marcelino-Guimarães, F. C., Seixas, C. D. S., and Carneiro, G. E. S. 2013. First report of Curtobacterium flaccumfaciens pv. flaccumfaciens on soybean in Brazil. Trop. Plant Pathol. 38:452-454.

Stoeva, N., Berova, M., and Zlatev, Z. 2005. Effect of arsenic on some physiological parameters in bean plants. Biol. Plant. 49:293-296.

Tamura, K., Stecher, G., Peterson, D., Filipski, A., and Kumar, S. 2013. MEGA6: Molecular evolutionary genetics analysis version 6.0. Mol. Biol. Evol. 30:2725-2729.

Tegli, S., Sereni, A., and Surico, G. 2002. PCR-based assay for the detection of Curtobacterium flaccumfaciens pv. flaccumfaciens in bean seeds. Lett. Appl. Microbiol. 35:331-337.

Thapa, S. P., Pattathil, S., Hahn, M. G., Jacques, M.-A., Gilbertson, R. L., and Coaker, G. 2017. Genomic analysis of Clavibacter michiganensis reveals insight into virulence strategies and genetic diversity of a gram-positive bacterial pathogen. Mol. Plant-Microbe Interact. 30:786-802.

Versalovic, J., Schneider, M., de Bruijn, F. J., and Lupski, J. R. 1994. Genomic fingerprinting of bacteria using repetitive sequence-based polymerase chain reaction. Methods Mol. Cell. Biol. 5:25-40.

Yasuhara-Bell, J., and Alvarez, A. M. 2015. Seed-associated subspecies of the genus Clavibacter are clearly distinguishable from Clavibacter michiganensis subsp. michiganensis. Int. J. Syst. Evol. Microbiol. 65: 811-826.

Young, J. M., Watson, D. R. W., and Dye, D. W. 2004. Reconsideration of Arthrobacter ilicis (Mandel et al. 1961) Collins et al. 1982 as a plantpathogenic species. Proposal to emend the authority and description of the species. Request for an opinion. Int. J. Syst. Evol. Microbiol. 54: 303-305. 